\title{
Adhesion of coagulase-negative staphylococci to methacrylate polymers and copolymers
}

\author{
A. H. Hogt \\ Department of Chemical Technology, Twente University of Technology, PO Box 217, 7500 AE \\ Enschede, The Netherlands
}

J. Dankert

Department of Hospital Epidemiology, University Hospital, Oostersingel 59, 9700 RB

Groningen, The Netherlands

\section{J. Feijen}

Department of Chemical Technology, Twente University of Technology, PO Box 217, 7500 AE Enschede, The Netherlands

Adhesion of coagulase-negative staphylococci (CNS) was studied onto a homologous series of methacrylate polymers and copolymers. The materials varied in wettability (contact angles) and were either positively or negatively charged (zetapotential). Bacterial adhesion experiments performed in a parallel-plate perfusion system showed that positively charged TMAEMA-Cl copolymers significantly promoted the adhesion of CNS as compared with all other methacrylate (co)polymers tested. The bacterial adhesion rates onto the positively charged surfaces are diffusion-controlled, whereas those onto the surfaces with a negative zeta-potential are more surface-reaction-controlled due to the presence of a potential energy barrier. The bacterial adhesion rates onto various poly (alkyl methacrylates) were similar. The number of adhering bacteria onto the negatively charged MMA/MAA copolymer did not differ from that onto $\mathrm{PMMA}$, indicating that sufficient sites on the copolymer surface with the same potential energy barrier as that on pMMA, were available for adhesion. Decreasing rates of adhesion of CNS were observed onto MMA/HEMA copolymers with increasing HEMA content coinciding with increasing hydrophilicity. Low plateau values for the bacterial adhesion were observed on 50MMA/50HEMA, pHEMA, and 85HEMA/15MAA, indicating that the adhesion onto these materials was reversible. Four CNS strains with different surface characteristics all showed higher numbers of adhering bacteria onto $85 \mathrm{MMA} / 15 \mathrm{TMAEMA}-\mathrm{Cl}$ than onto 85MMA/15MAA and pMMA.

\section{INTRODUCTION}

Bacterial adhesion onto biomaterials is an essential step in the pathogenesis of implant- and medical-device-associated infections. ${ }^{1-3}$ Most of these infections are caused by coagulase-negative staphylococci (CNS), in particular by Staphylococcus epidermidis. ${ }^{4}$

In vitro studies showed that the ability of bacteria to adhere onto suture materials, ${ }^{5-7}$ vascular grafts, ${ }^{8}$ and intravascular catheters ${ }^{9}$ varied depending

Journal of Biomedical Materials Research, Vol. 20, 533-545 (1986)

(C) 1986 John Wiley \& Sons, Inc.

CCC 0021-9304/86/040533-13\$04.00 
on the nature of the biomaterials. Because the biomaterial surfaces were not characterized in these studies, clear-cut relations between bacterial adhesion and material surface properties were not obtained. Fletcher and Loeb ${ }^{10}$ and Pringle et al. ${ }^{11}$ demonstrated that the adhesion of marine bacteria onto glass and various polymers was related to the wettability of the materials as determined by water contact angles. Numbers of adhering bacteria were reported to be maximal on materials with water contact angles between $65^{\circ}$ and $85^{\circ}$ and to decrease on materials with lower and higher contact angles. A relationship between the adhesion of Candida species and the wettability of different denture base resins was reported by Minagi et al. ${ }^{12}$ Onto materials with decreasing water contact angles, increasing adhesion of Candida albicans and decreasing adhesion of Candida tropicalis were observed. The numbers of adhering microorganisms were suggested to be higher if the surface free energy of the materials was closer to that of the microorganisms and to decrease when materials had higher or lower surface free energies than that of the microorganisms.

Series of methacrylate polymers and copolymers have been used to study the adhesion of thrombocytes and mouse fibroblasts as a function of material wettability and surface potential. ${ }^{13-15}$ Decreased adhesion of thrombocytes and fibroblasts was observed on more hydrophilic copolymers. ${ }^{13,14}$ However, hydrophilic copolymers with positive surface charge appeared to promote cellular adhesion. ${ }^{15}$ In order to study the effect of material surface properties on the in vitro adhesion of CNS, we also used a homologous series of methacrylate polymers and copolymers which varied in wettability and were either negatively or positively charged. ${ }^{16}$ The bacterial adhesion experiments were performed with various CNS strains in a parallel-plate perfusion system which was placed in a vertical position to prevent bacterial sedimentation. Low flow rates were used in order to obtain laminar flow in the perfusion chambers with minimal turbulence at the entry site and to test bacterial adhesion at a low shear rate.

\section{MATERIALS AND METHODS}

\section{Bacteria}

Two strains of Staphylococcus epidermidis (strains SEP 1 and NCTC 100835) and two strains of Staphylococcus saprophyticus (strains GB 171 and SAP 1) were used. SEP 1, NCTC 100835 and GB 171 were isolated from the blood of patients with sepsis, SAP 1 was isolated from the skin of a patient. Bacteria were grown overnight in Trypticase soy broth (TSB, BBL. Microbiology Systems, Cockeysville, MD) and were subcultured for $4.5 \mathrm{~h}$ at $37^{\circ} \mathrm{C}$ in TSB to the late logarithmic growth phase. Bacteria were sedimented by centrifugation $\left(10,000 \mathrm{~g}, 10 \mathrm{~min}, 4^{\circ} \mathrm{C}\right)$, washed twice with phosphate buffered saline (PBS; $140 \mathrm{mM} \mathrm{NaCl}, 3 \mathrm{mM} \mathrm{KCl}, 8.1 \mathrm{mM} \mathrm{Na}_{2} \mathrm{HPO}_{4}, 1.5 \mathrm{mM} \mathrm{KH}_{2} \mathrm{PO}_{4}$, $\mathrm{pH} 7.2$ ) and were then resuspended in PBS. These suspensions were aspirated and ejected twice through a 25 -gauge needle, filtered through a $3-\mu \mathrm{m}$ mem- 
brane (Unipore, Biorad Laboratories, Richmond, CA) and adjusted to an optical density (O.D.) $=1.0$, corresponding with a bacterial cell concentration of approximately $1 \times 10^{9}$ colony forming units (cfu) per $\mathrm{mL}$ as determined by pour plate technique. In some experiments bacterial suspensions adjusted to an O.D. $=0.5$ and 0.1 were used.

The bacteria were characterized by determining the presence of an extracellular capsule, the cell-surface hydrophobicity and the relative surface charge. The presence or absence of capsules was demonstrated in India ink wet-film preparations of washed bacterial cells according to Duguid. ${ }^{17}$ The bacterial cell surface hydrophobicity determined in a xylene-water twophase system according to Rosenberg et al. ${ }^{18}$ was expressed as the percentage of bacteria adhering to the hydrocarbon phase after agitation of a $3 \mathrm{~mL}$ suspension in PBS containing $10^{9} \mathrm{cfu} \mathrm{mL} \mathrm{m}^{-1}$ for $60 \mathrm{~s}$ with $0.25 \mathrm{~mL}$ of $p$-xylene (Merck, Darmstadt, F.R.G.). ${ }^{19}$ Anion-exchange chromatography was used to determine the relative bacterial surface charge.$^{20,21}$ Washed bacteria $\left(1 \times 10^{9} \mathrm{cfu}\right)$ suspended in $330 \mathrm{mM} \mathrm{NaCl} /$ phosphate buffer were applied to a column containing $0.5 \mathrm{~g}$ Dowex $1 \times 8$ anion-exchange resin (mesh size $100 / 200,80-150 \mu \mathrm{m}$, Serva, Heidelberg, F.R.G.) and eluted with $330 \mathrm{mM}$ $\mathrm{NaCl} /$ phosphate buffer. The relative bacterial surface charge was expressed as the percentage of bacteria bound to the anion-exchange resin.

\section{Materials}

The materials used in this study were methacrylate polymers and copolymers coated on glass slides or silanized glass slides ${ }^{16}:$ poly(methyl methacrylate) (pMMA); poly(hydroxyethyl methacrylate) (pHEMA); copolymers of MMA with HEMA (mol percentages $75 / 25$ and 50/50); copolymers of MMA with $15 \%$ methacrylic acid (MAA) or $15 \%$ trimethylaminoethyl methacrylate (TMAEMA, $\mathrm{HCl}$ salt); copolymers of HEMA with $15 \%$ MAA or $15 \%$ TMAEMA-Cl; poly(hexyl methacrylate) (pHMA) and poly(dodecyl methacrylate) (pDDMA). Materials were prepared under clean-room conditions and stored in sealed boxes. No sterilization procedure was applied.

The material surfaces were characterized by water contact angle and zetapotential measurements. Advancing and receding water contact angles on the materials were determined by the Wilhelmy-plate technique. ${ }^{16,22}$ The material surface zeta-potentials were calculated from streaming potential measurements using a buffer containing $0.01 \mathrm{M} \mathrm{KCl}$ and $1 \mathrm{mM}$ phosphate $\left(\mathrm{pH} \mathrm{7.4).}{ }^{16,23}\right.$

\section{Perfusion system}

The experimental set-up for the bacterial adhesion tests consisted of two 60 -mL syringes (BBL Microbiology systems) attached via medical grade silicone rubber tubing $(3.0 \times 5.0 \mathrm{~mm})$ to a three-way valve and a perfusion 


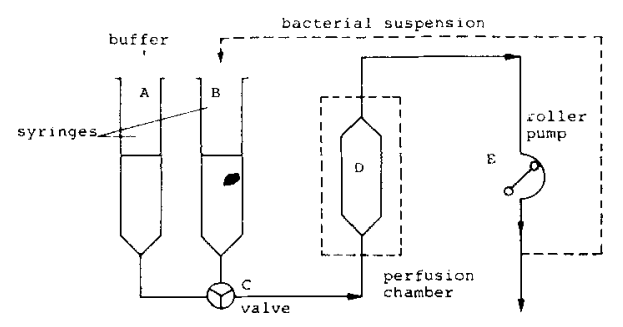

A. PERFUSION SYSTEM

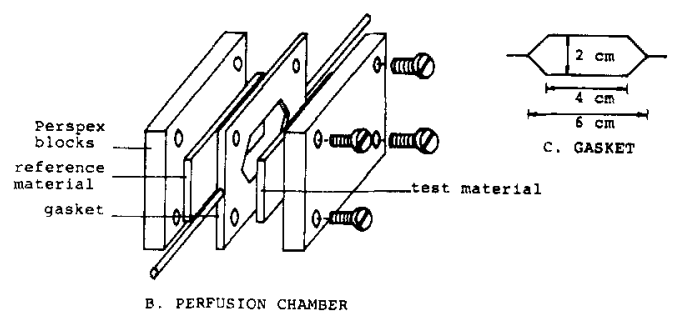

Figure 1. (a) Schematic representation of the perfusion system; (b) exploded view of the perfusion chamber; (c) dimensions of the perfusion chamber gasket.

chamber (Fig. 1). In this chamber two material plates separated by a silicone rubber gasket (thickness $3 \mathrm{~mm}$ ) with in- and outflow tubing were clamped between two Perspex blocks. The surface area of each plate exposed to the perfusion medium was $10 \mathrm{~cm}^{2}$. The chamber was set up vertically and could be rotated upside down. The volume of the chamber was $3 \mathrm{~mL}$. The tubing from the perfusion chamber was led through a rollerpump (type 2132, Microperpex peristaltic pump, LKB, Bromma, Sweden) and then led to a bottle or back to one of the syringes. The volume of the entire tubing was $10 \mathrm{~mL}$. Four similar perfusion systems were set up and simultaneously used in the experiments. Prior to the experiments the syringes and tubing were perfused for 30 min with PBS. Each perfusion chamber contained one test material and one reference material (pMMA). The entire perfusion system was placed in a room in which the temperature was kept at $37^{\circ} \mathrm{C}$ and primed with PBS for $2 \mathrm{~h}$. The pump was always calibrated to give a flow rate of $1 \mathrm{~mL} \mathrm{~min}{ }^{-1}$.

Before each experiment the tubing of the perfusion system was replaced and the syringe containers and perfusion chamber gaskets were ultrasonically cleaned for $15 \mathrm{~min}$ in a RBS 25 (Hicol, Rotterdam, The Netherlands; $1 \% \mathrm{v} / \mathrm{v}$ ) soap solution and subsequently rinsed for at least $15 \mathrm{~min}$ with hot tap water and sterilized distilled water.

\section{Exposure of materials to bacterial suspensions}

After priming with PBS, the chambers were perfused upwards with a bacterial suspension in PBS for $30 \mathrm{~min}$. Thereafter a bacterial suspension 
(25 mL) was recirculated. Each series of perfusion experiments with one type of test material was performed on two days; perfusion periods were $0.5,1.5$, 2.5 , and $3.5 \mathrm{~h}$ on the first day and 1.0, 2.0,3.0, and $4.0 \mathrm{~h}$ on the second day. After various time intervals the perfusion chambers were successively rinsed with PBS for $30 \mathrm{~min}$, with PBS containing 2\% (v/v) glutaraldehyde for $15 \mathrm{~min}$ and with distilled water for $45 \mathrm{~min}$ in order to remove the nonadhering bacteria and to fix the adhering bacteria. The perfusion chambers were turned upside down to achieve the proper replacement of the successive rinsing fluids. After the last rinse the materials were removed from the chamber and examined under a light microscope. The number of adhering bacteria onto the test materials $\left(x_{i}\right)$ and the pMMA reference material $\left(y_{i}\right)$ were counted on eight $0.05 \mathrm{~mm}^{2}$ areas $(i=1,2, \ldots, 8)$ which were $0.5 \mathrm{~cm}$ apart on the axial midline of the slides at a distance of 1.5 to $5.0 \mathrm{~cm}$ from the entrance of the chamber. Mean numbers of adhering bacteria onto the test materials $(\bar{X})$ after each perfusion period were calculated from

$$
\bar{X}=\frac{1}{8} \sum_{i=1}^{i=8} \frac{x_{i}}{y_{i}} \cdot \bar{y}_{i} \quad(i=1,2, \ldots, 8)
$$

$\bar{y}_{i}$ Represents the mean number of adhering bacteria onto pMMA per area at the same axial distance calculated from the number of adhering bacteria $\left(y_{i j}\right)$ determined in all $(j=1,2, \ldots, n)$ experiments:

$$
\bar{y}_{i}=\frac{1}{n} \sum_{j=1}^{j=n} y_{i j}
$$

The mean number of adhering bacteria onto pMMA at all areas for each perfusion period $(\bar{Y})$ were calculated from $\bar{y}_{i}$ :

$$
\bar{Y}=\frac{1}{8} \sum_{i=1}^{i=8} \bar{y}_{i}
$$

From $y_{i j}$ also the mean number of adhering bacteria onto pMMA onto all areas per experiment $\left(\bar{y}_{j}\right)$ was calculated for each perfusion period:

$$
\bar{y}_{j}=\frac{1}{8} \sum_{i=1}^{i=8} y_{i j}
$$

In order to study the effect of the bacterial cell concentration on the bacterial adhesion onto the pMMA reference material, suspensions containing $0.1 \times 10^{9}, 0.5 \times 10^{9}$, and $1.0 \times 10^{9} \mathrm{cfu} \mathrm{mL}^{-1} \mathrm{PBS}$ were used. To study the effect of the salt concentration on the bacterial adhesion, in one experiment PBS was replaced by a buffer containing $1 \mathrm{mM}$ phosphate ( $\mathrm{pH}$ 7.2). The adhesion of four different CNS strains was determined after a perfusion period of $2.5 \mathrm{~h}$.

The O.D. of aliquots taken from the recirculating bacterial suspension during the perfusion was measured at various intervals to determine the bacterial reaggregation. ${ }^{24}$ 


\section{Statistical methods}

Student's $t$-test ${ }^{25}$ was used to determine significant differences $(p<0.05)$ between numbers of adhering bacteria onto test materials and those onto the pMMA reference material. Adhesion values $\left(x_{i}\right.$ and $\left.y_{i}\right)$ on the materials at different axial distances $(i)$ were compared as paired variates.

\section{RESULTS}

Two encapsulated and two nonencapsulated CNS strains were used (Table I). The cell surface of two strains had a hydrophobic character. Two strains were hydrophilic. The hydrophilic nonencapsulated strain had a higher surface charge than the other (hydrophobic) nonencapsulated strain. Both encapsulated strains had a rather high relative surface charge.

Characterization of the material surfaces showed that receding contact angles of MMA copolymers containing hydrophilic HEMA, charged TMAEMA-Cl or charged MAA groups were much lower than that of pMMA, whereas the advancing contact angles were only slightly decreased (Table II). Charged HEMA/TMAEMA-Cl and HEMA/MAA copolymers and pHEMA showed similar receding contact angles. The advancing contact angles of the HEMA/MAA and HEMA/TMAEMA-Cl copolymers were higher than that of pHEMA. The three poly(alkyl methacrylates) showed increased advancing contact angles with increasing side chain length. The receding contact angle of pHMA was higher than that of PMMA and pDDMA, which were similar. Introduction of TMAEMA-Cl or MAA groups in MMA and HEMA polymers yielded copolymers with either a positive or an increased negative zeta-potential.

In the parallel-plate perfusion system, higher numbers of S. epidermidis (SEP 1) adhered onto pMMA when perfusion periods were prolonged and when the initial bacterial cell concentration was increased (Fig. 2). The O.D. of the S. epidermidis (SEP 1) suspensions decreased to $60 \%$ of the initial value

TABLE I

Surface Characteristics of the Bacterial Strains

\begin{tabular}{|c|c|c|}
\hline Staphylococcus strains & $\begin{array}{c}\text { Capsule hydrophobicity }^{\mathrm{b}} \\
(\%)\end{array}$ & $\begin{array}{l}\text { Relative surface } \\
\text { charge }^{c}(\%)\end{array}$ \\
\hline S. epidermidis(SEP 1) & 80 & 23 \\
\hline S. epidermidis(NCTC 100835) & - & 70 \\
\hline S. saprophyticus(GB 171) & 89 & 96 \\
\hline S. saprophyticus(SAP 1) & + & 79 \\
\hline
\end{tabular}

aPresence $(+)$ or absence $(-)$ of extracellular capsules demonstrated by the India ink method. ${ }^{17}$

${ }^{b}$ Expressed as the percentage of bacteria adhering to xylene in a xylene/water system. ${ }^{18,19}$

'Expressed as the percentage of bacteria adhering to an anion-exchange resin in column chromatography. ${ }^{20,21}$ 
TABLE II

Water Contact Angles and Zeta-potentials of Methacrylate (Co)polymers

\begin{tabular}{|c|c|c|c|}
\hline \multirow[b]{2}{*}{ (Co)Polymer of } & \multicolumn{2}{|c|}{$\begin{array}{l}\text { Contact angles } \\
\text { (degrees) }\end{array}$} & \multirow{2}{*}{$\begin{array}{l}\text { Zeta-potentials } \\
(\mathrm{mV})\end{array}$} \\
\hline & Advancing & Receding & \\
\hline $\mathrm{pMMA}^{\mathrm{a}}$ & 80 & 57 & -29 \\
\hline 75MMA/25HEMA & 73 & 39 & $\mathrm{ND}^{\mathrm{b}}$ \\
\hline 50MMA/50HEMA & 69 & 26 & ND \\
\hline pHEMA & 72 & 4 & -8 \\
\hline 85MMA/15TMAEMA-Cl ${ }^{\mathrm{c}}$ & 71 & 1 & +4 \\
\hline $85 \mathrm{MMA} / 15 \mathrm{MAA}^{\mathrm{c}}$ & 70 & 4 & -41 \\
\hline 85HEMA/15TMAEMA-Cl & 103 & 2 & +5 \\
\hline 85HEMA/15MAA ${ }^{\mathrm{c}}$ & 88 & 3 & -24 \\
\hline pHMA & 99 & 74 & ND \\
\hline pDDMA & 115 & 60 & ND \\
\hline
\end{tabular}

${ }^{\mathrm{a}}$ For abbreviations see Materials and Methods.

${ }^{\mathrm{b}} \mathrm{ND}$, not determined.

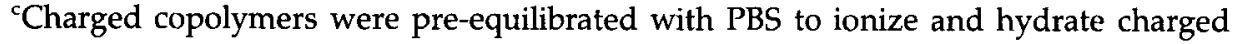
groups.

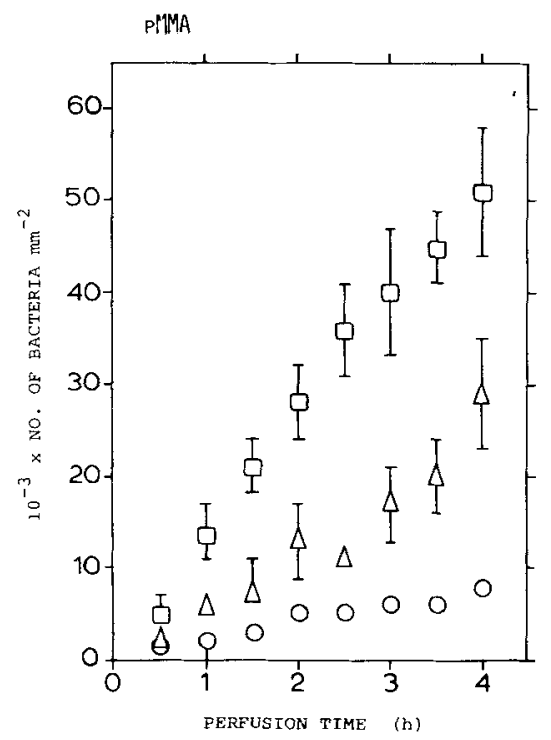

Figure 2. Number of adhering S. epidermidis (SEP 1) onto pMMA as a function of bacterial cell concentration and perfusion time. Initial bacterial cell concentration in the suspension was $0.1 \times 10^{9}(0), 0.5 \times 10^{9}(\triangle)$, and $1.0 \times 10^{9}$ (ㅁ) cells $\mathrm{mL}^{-1}$. Bars represent standard deviations larger than symbol size.

during perfusion for $4 \mathrm{~h}$ (results not shown). The numbers of adhering $S$. epidermidis (SEP 1) onto pMMA $\left(\bar{y}_{j}\right)$ from suspensions containing $10^{9} \mathrm{cfu} \mathrm{\textrm {mL } ^ { - 1 }}$ ranged from $38 \times 10^{3}$ to $65 \times 10^{3}$ cells $\mathrm{mm}^{-2}$ after $4 \mathrm{~h}$ perfusion. 
The bacterial adhesion onto the test materials was determined with suspensions containing $10^{9} \mathrm{cfu} \mathrm{mL} \mathrm{mL}^{-1}$ using pMMA as a reference material. $S$. epidermidis (SEP 1) adhered less onto the MMA/HEMA copolymers and pHEMA than onto pMMA (Fig. 3). After $1.5 \mathrm{~h}$ perfusion, the difference in numbers of adhering bacteria onto the MMA/HEMA copolymers and pHEMA and those onto pMMA was statistically significant $(p<0.05)$. Bacterial adhesion onto $50 \mathrm{MMA} / 50 \mathrm{HEMA}$ and pHEMA did not increase as a function of perfusion time. The numbers of adhering bacteria onto pHMA and PDDMA were similar to those onto pMMA (results not shown).

S. epidermidis (SEP 1) adhered in much higher numbers onto the MMA/TMAEMA-Cl and HEMA/TMAEMA-Cl copolymers than onto pMMA (Fig. 4). The numbers of adhering bacteria increased with perfusion time. After $1.5 \mathrm{~h}$ perfusion differences were significant. The bacterial adhesion onto $85 \mathrm{MMA} / 15 \mathrm{MAA}$ was similar to that onto pMMA (Fig. 4). On 85 HEMA/15 MAA bacteria adhered slightly. The numbers of adhering bacteria onto this copolymer were not significantly different from those on pHEMA (Fig. 3).

Numbers of adhering S. epidermidis (SEP 1) onto $85 \mathrm{MMA} / 15 \mathrm{MAA}$ and pMMA from suspensions in buffer containing $1 \mathrm{mM}$ phosphate were significantly lower than those from suspensions in PBS (Table III).

Each of the four CNS strains tested showed significantly higher numbers of adhering bacteria onto $85 \mathrm{MMA} / 15 \mathrm{TMAEMA}-\mathrm{Cl}$ than onto $85 \mathrm{MMA}$ / 15 MAA and pMMA (Table IV).

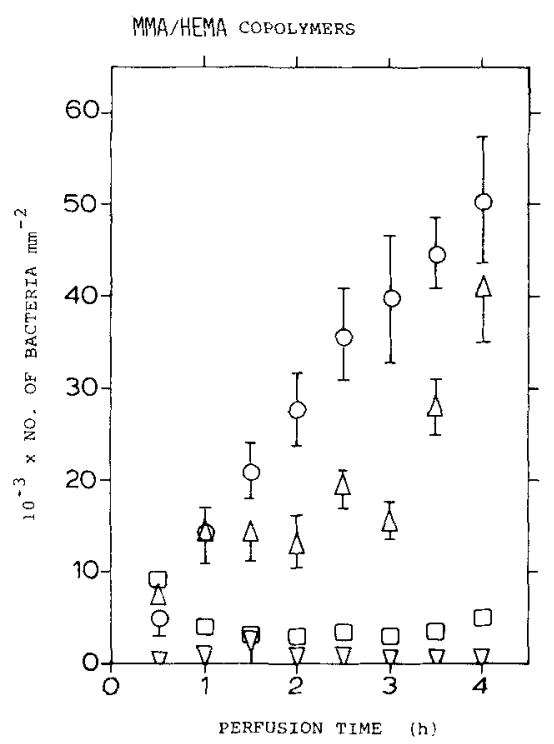

Figure 3. Numbers of adhering $S$. epidermidis (SEP 1) onto MMA/HEMA copolymers as a function of perfusion time; pMMA (O), $75 \mathrm{MMA} / 25 \mathrm{HEMA}$ $(\triangle), 50 \mathrm{MMA} / 50 \mathrm{HEMA}(\square)$, and pHEMA $(\nabla)$. 


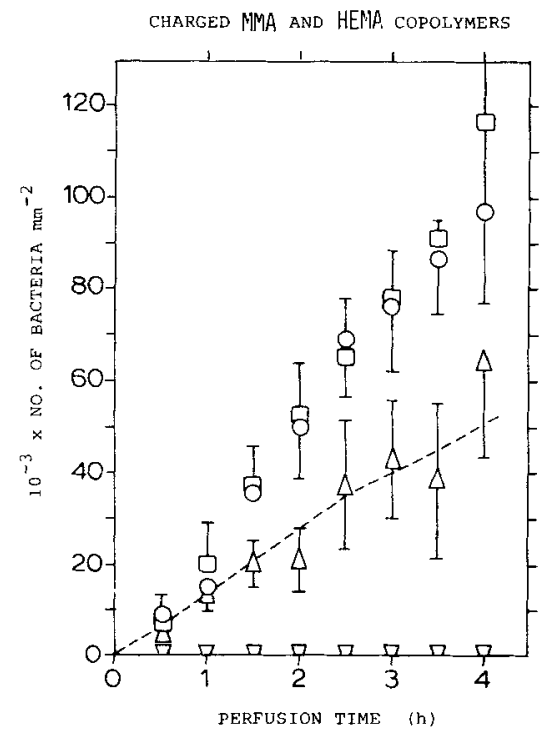

Figure 4. Numbers of adhering $S$. epidermidis (SEP 1) onto charged MMA and HEMA copolymers as a function of perfusion time: $85 \mathrm{MMA} / 15$ TMAEMA-Cl (०), 85 MMA/15 MAA $(\triangle), 85 \mathrm{HEMA} / 15$ TMAEMA-Cl $(\square)$, and 85 HEMA/15 MAA $(\nabla)$. Dashed curve indicates the mean adhesion values on pMMA (reference).

TABLE III

Numbers of Adhering S. epidermidis (SEP 1) onto 85 MMA/15 MAA and pMMA from Suspensions in Two Buffers with Different Salt Concentrations

\begin{tabular}{ccc}
\hline & \multicolumn{2}{c}{$10^{-3} \times$ No. of bacteria $\mathrm{mm}^{-2 \mathrm{a}}$} \\
\cline { 2 - 3 } Buffer & $85 \mathrm{MMA} / 15 \mathrm{MAA}$ & pMMA \\
\hline $10 \mathrm{mM}$ phosphate, $140 \mathrm{mM} \mathrm{NaCl}$ and $3 \mathrm{mM} \mathrm{KCl}$ (PBS) & $25.8 \pm 10.0$ & $36.1 \pm 4.2$ \\
$1 \mathrm{mM}$ phosphate & $9.0 \pm 4.5^{*}$ & $11.1 \pm 1.9^{*}$ \\
\hline
\end{tabular}

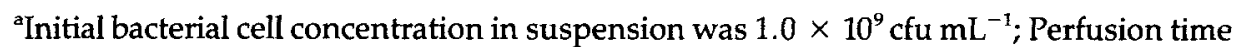
was $2.5 \mathrm{~h}$.

${ }^{*}$ Denotes significant difference between adhesion values in $1 \mathrm{mM}$ phosphate buffer and in PBS $(p<0.001)$. Adhesion values onto 85 MMA/15 MAA were not significantly different from those onto pMMA in both buffers.

\section{DISCUSSION}

The rate of adhesion of bacteria onto a solid surface may be influenced by the bacterial diffusion towards the surface and/or by the reaction of the bacteria with the surface. ${ }^{26,27}$ Transfer of bacteria to the surface is governed by the hydrodynamic conditions present. When bacteria approach the surface, long-range interactions, resulting from London dispersion forces and electrostatic forces occur. According to the D.L.V.O. theory, the potential 
TABLE IV

Numbers of Adhering S. epidermidis (SEP 1 and NCTC 100835) and S. saprophyticus (GB 171 and SAP 1) onto 85 MMA/15 TMAEMA-Cl, 85 MMA/15 MAA and pMMA

\begin{tabular}{lcrr}
\hline \multirow{2}{*}{$\begin{array}{c}\text { Staphylococcus } \\
\text { strain }\end{array}$} & 85MMA/15TMAEMA-Cl & 85MMA/15MAA & pMMA \\
\cline { 2 - 4 } \multicolumn{1}{c}{ SEP 1 } & $68.8 \pm 8.4^{*}$ & $36.9 \pm 13.6$ & $36.1 \pm 4.2$ \\
NCTC 100835 & $36.0 \pm 5.9^{*}$ & $15.4 \pm 3.4$ & $17.1 \pm 2.6$ \\
GB 171 & $28.3 \pm 8.3^{*}$ & $7.5 \pm 1.5$ & $7.9 \pm 2.5$ \\
SAP 1 & $23.5 \pm 4.2^{*}$ & $1.2 \pm 0.4$ & $1.9 \pm 0.3$ \\
\hline
\end{tabular}

${ }^{a}$ Initial bacterial cell concentration in suspension was $1.0 \times 10^{9} \mathrm{cfu} \mathrm{mL}^{-1}$; Perfusion time was $2.5 \mathrm{~h}$.

*Denotes significant difference with respect to adhesion values onto pMMA $(p<0.001)$.

energy between the bacteria and the surface depends mainly on the separation distance, the surface potentials and the composition of the liquid medium. ${ }^{28}$ For bacterial adhesion to occur the potential energy has to be negative. The potential energy between bacteria and substrata with potentials of the same sign usually shows a maximum at a certain distance of separation, providing an energy barrier for adhesion. Bacteria may (reversibly) adhere at a distance from the surface due to the presence of a secondary shallow minimum in the potential energy. Bacteria which are able to overcome the energy barrier will reach the surface and may adhere if the potential energy due to short-range interactions $(<4 \AA$ ), resulting from chemical bonds, dipole interactions and/or hydrophobic interactions is sufficiently negative. ${ }^{29}$

The rate of adhesion of $S$. epidermidis (SEP 1) onto the two positively charged TMAEMA-Cl copolymers was significantly higher than onto all other methacrylate (co)polymers tested. Because the bacteria are negatively charged, they are attracted by the positively charged surfaces and therefore the adhesion process onto these materials is diffusion-controlled. ${ }^{27}$ The rate of adhesion of bacteria onto the materials with a negative zeta-potential was decreased due to the presence of a potential energy barrier and therefore becomes additionally controlled by the surface reaction.

The adhesion rate of $S$. epidermidis onto the MMA/MAA copolymer did not differ from that onto pMMA, although this copolymer showed a more negative zeta-potential than pMMA. It has to be noted that zeta-potentials were determined in a buffer containing $0.01 \mathrm{M} \mathrm{KCl}$ and $1 \mathrm{mM}$ phosphate and that adhesion experiments were performed using bacterial suspensions in PBS in which zeta-potentials are less negative. Although the number of adhering bacteria decreased in experiments using $1 \mathrm{mM}$ phosphate buffer, the rate of adhesion was similar onto both the MMA/MAA copolymer and pMMA. Apparently, sufficient sites on the copolymer surface having the same potential energy barrier as pMMA, were available for bacterial adhesion. 
Changing the length of the alkyl side chains in the poly(alkyl methacrylates) did not affect the kinetics of the adhesion of $S$. epidermidis (SEP 1).

The increase of the HEMA content in MMA/HEMA copolymers coinciding with a decrease in receding contact angles, resulted in lower rates of adhesion of $S$. epidermidis (SEP 1). Low plateau values for the bacterial adhesion were observed with 50MMA/50HEMA, pHEMA and 85HEMA/15MAA, which suggests that the adhesion onto these materials is reversible. Several investigators have studied the adhesion of microorganisms onto material surfaces with different wettabilities. ${ }^{11,12}$ In these studies advancing contact angles were used as surface parameters, although the use of receding contact angles probing the surface in water, ${ }^{30}$ would be more appropriate. In addition, the numbers of adhering microorganisms found after a certain time on the materials may be kinetically controlled by an energy barrier and therefore cannot directly be related to the surface free energy (contact angles) of the materials and the free energy for adhesion.

Adhesion experiments with four CNS strains differing in their surface characteristics showed that the numbers of adhering bacteria of all four strains were higher onto the positively charged MMA/TMAEMA-Cl copolymer than onto the negatively charged MMA/MAA copolymer and pMMA. Differences in the rates of adhesion of the strains onto each of the (co)polymers could not be related to a particular surface property of the strains, but may be caused by the presence of specific domains at the bacterial surface. ${ }^{31}$ The significance of the heterogeneity of the bacterial cell surface in relation to the adhesion of encapsulated and nonencapsulated CNS onto biomaterials has still to be elucidated.

We thank Prof. Dr. J. D. Andrade, Dr. D. E. Gregonis and Prof. Dr. S. W. Kim (University of Utah, Salt Lake City, Utah) for their support of the work on the synthesis and surface characterization of the materials. We gratefully acknowledge a grant from the Netherlands Organization for the Advancement of Pure Research (ZWO), The Hague.

\section{References}

1. W. P. Reed and R. C. Williams, "Bacterial adherence: first step in pathogenesis of certain infections," J. Chron. Dis., 31, 67-72 (1978).

2. W.S. Moore, J.M. Malone, and K. Keown, "Prosthetic arterial graft material," Arch. Surg., 115, 1379-1383 (1980).

3. A. G. Gristina and J.W. Costerton, "Bacterial adherence to biomaterials: the clinical significance of its role in sepsis," Biomaterials Trans., 7, 175 (1984).

4. F. D. Lowy and S. M. Hammer, "Staphylococcus epidermidis infections," Ann. Intern. Med., 99, 834-839 (1983).

5. B. Sugarman and D. Musher, "Adherence of bacteria to suture materials," Exp. Biol. Med., 167, 156-160 (1981).

6. S. Katz, M. Izhar, and D. Mirelman, "Bacterial adherence to surgical sutures," Ann. Surg., 194, 35-41 (1981).

7. C.C. Chu and D.F. Williams, "Effect of physical configuration and chemical structure of suture materials on bacterial adhesion," Am. J. Surg., 147, 197-204 (1984). 
8. B. Sugarman, "In vitro adherence of bacteria to prosthetic vascular grafts," Infection, 10, 9-12 (1981).

9. N. K. Sheth, H.D. Rose, T.R. Franson, F. L. A. Buckmire, and P. G. Sohnle, "In vitro quantitative adherence of bacteria to intravascular catheters," J. Surg. Res., 34, 213-218 (1983).

10. M. Fletcher and G. I. Loeb, "Influence of substratum characteristics on the attachment of a marine Pseudomonas to solid surfaces," Appl. Environ. Microbiol., 37, 67-72 (1979).

11. J. H. Pringle, M. Fletcher, and D. C. Ellwood, "Selection of attachment mutants during the continuous culture of Pseudomonas fluorescens and relationship between attachment ability and surface composition," J. Gen. Microbiol., 129, 2557-2569 (1983).

12. S. Minagi, Y. Miyake, K. Inagaki, H. Tsuru, and H. Suginaka, "Hydrophobic interaction in Candida albicans and Candida tropicalis adherence to various denture base resin materials," Infect. Immun., 47, 11-14 (1985).

13. D. L. Coleman, D.E. Gregonis, and J.D. Andrade, "Blood-materials interactions: The minimum interfacial energy and the optimum polar/apolar ratio hypothesis," J. Biomed. Mater. Res., 16, 381-398 (1982).

14. T. A. Horbett, M. B. Schway, and B. D. Ratner, "Hydrophilichydrophobic copolymers as cell substrates: effect on 3T3 cell growth rates," J. Colloid Interface Sci., 104, 28-39 (1985).

15. S. Hattori, J. D. Andrade, J. B. Hibbs, D. E. Gregonis; and R. N. King, "Fibroblast cell proliferation on charged hydroxyethyl methacrylate copolymers," J. Colloid Interface Sci., 104, $72-78$ (1985).

16. A. H. Hogt, D. E. Gregonis, J. D. Andrade, S. W. Kim, J. Dankert, and J. Feijen, "Wettability and zeta-potentials of a series of methacrylate polymers and copolymers," J. Colloid Interface Sci., 106, 289-298 (1985).

17. J.P. Duguid, "The demonstration of bacterial capsules and slime," J. Pathol. Bacteriol., 63, 673-685 (1951).

18. M. Rosenberg, D. Gutnick, and E. Rosenberg, "Adherence of bacteria to hydrocarbons: A simple method for measuring cell-surface hydrophobicity," FEMS Microbiol. Lett., 9, 29-33 (1980).

19. A. H. Hogt, J. Dankert, and J. Feijen, "Encapsulation, slime production and surface hydrophobicity of coagulase-negative staphylococci," FEMS Microbiol. Lett., 18, 211-215 (1983).

20. K. Pedersen, "Electrostatic interaction chromatography, a method for assaying the relative surface charges of bacteria," FEMS Microbiol. Lett., 12, 365-367 (1981).

21. A. H. Hogt, J. Dankert, and J. Feijen, "Adhesion of Staphylococcus epidermidis and Staphylococcus saprophyticus onto a hydrophobic biomaterial," J. Gen. Microbiol., 131, 2485-2491 (1985).

22. A.W. Adamson, Physical Chemistry of Surfaces, 3rd ed., WileyInterscience, New York, 1976.

23. R. A. van Wagenen, D. L. Coleman, R. N. King, P. Triolo, L. Brostrom, L. M. Smith, D. E. Gregonis, and J.D. Andrade, "Streaming potential investigations: polymer thin films," J. Colloid Interface Sci., 84, 155-162 (1981).

24. A. H. Hogt, J. Dankert, J. A. de Vries, and J. Feijen, "Adhesion of coagulase-negative staphylococci to biomaterials," J. Gen. Microbiol., 129, 2959-2968 (1983).

25. R. A. Fisher and F. Yates, Statistical Methods for Biological, Agricultural and Medical Research, Oliver and Boyd, Ltd., Edinburgh, 1957.

26. V. G. Levich, Physicochemical Hydrodynamics, Prentice-Hall, New York, 1962 , p. 60.

27. B. D. Bowen and N. Epstein, "Fine particle deposition in smooth parallel-plate channels," J. Colloid Interface Sci., 72, 81-97 (1979). 
28. P. R. Rutter and B. Vincent, "The adhesion of micro-organisms to surfaces: Physicochemical aspects," in Microbial Adhesion to Surfaces, R. C. W. Berkeley, J. M. Lynch, J. Melling, P. R. Rutter, and B. Vincent, Eds., Ellis Horwood, Chichester, 1980, pp. 79-92.

29. Th. F. Tadros, "Particle-surface adhesion," Microbial Adhesion to Surfaces, R. C. W. Berkeley, J. M. Lynch, J. Melling, P. R. Rutter, and B. Vincent, Eds., Ellis Horwood, Chichester, 1980, pp. 93-116.

30. J. D. Andrade, D. E. Gregonis, and L. M. Smith, "Polymer-water interface dynamics," Physicochemical Aspects of Polymer Surfaces, Vol. 2, K. L. Mittal, Ed., Plenum Press, New York, 1982, pp. 911-922.

31. A. H. Hogt, J. Dankert, and J. Feijen, "Cell surface characteristics of coagulase-negative staphylococci and adherence onto fluorinated poly(ethylene-propylene)," Infect. Immun., 51, 294-301 (1986).

Received March 31, 1985

Accepted August 19, 1985 